\title{
ANALISIS PENGARUH PERKEMBANGAN TEKNOLOGI PERTANIAN DI ERA REVOLUSI INDUSTRI 4.0 TERHADAP HASIL PRODUKSI PADI
}

\section{ANALYZE THE IMPACT OF TECHNOLOGICAL DEVELOPMENT IN THE INDUSTRIAL REVOLUTION 4.0 ON RICE PRODUCTION}

\author{
Vini Putri Febrianti ${ }^{1 *}$, Tasya Alya Permata ${ }^{1}$, Mamai Humairoh ${ }^{1}$, Odita Mulyana Putri ${ }^{1}$, Lisa \\ Amelia $^{1}$, Shaynen Fatimah ${ }^{1}$, Rida Oktorida Khastini ${ }^{1}$
}

\author{
${ }^{1}$ Program Studi Pendidikan Biologi, Fakultas Keguruan dan Ilmu Pendidikan, Universitas Sultan Ageng \\ Tirtayasa, Jalan Ciwaru Raya, Cipare, Kecamatan Serang, Kota Serang, Provinsi Banten
}

\begin{abstract}
ABSTRAK
Penelitian ini memuat mengenai perkembangan revolusi industri. Jurnal ini dibahas mengenai faktorfaktor yang mempengaruhi perkembangan revolusi industri, dan pengaruh dari hasil produksi padi dengan tingkat penerapan teknologi PTT dan SRI. Tujuan dari penelitian ini yaitu untuk mendeskripsikan dan mengetahui pengaruh perkembangan revolusi industri. Penelitian ini menggunakan salah satu metode pendekatan yaitu kualitatif deskristif, yang memiliki tujuan untuk mengetahui nilai variabel, tanpa menciptakan, membandingkan, dan mencari hubungannya. Pengambilan sampel yang dilakukan pada penelitian ini dengan cara purposive sample. Purposive sampel adalah pengambilan sampel dengan memberikan ciri-ciri khusus yang sesuai dengan tujuan penelitian. Hasil penelitian memperlihatkan faktor yang paling besar dalam mempengaruhi kehidupan masyarakat adalah perkembangan teknologi. Teknologi yang digunakan untuk mengetahui tingkat penerapan yang dilakukan pada penelitian ini yaitu teknologi dengan metode PTT dan metode SRI. Hasil dari keduanya sangat berbeda, dimana metode PTT lebih mampu memberikan hasil yang lebih unggul. Pada data tercatat bahwa metode SRI dalam kurun waktu tertentu mengalami penurunan dari musim ke musim.
\end{abstract}

Kata kunci: Revolusi industri, PTT, SRI, Sampel purposif.

\begin{abstract}
This research contains about the development of the industrial revolution. This research is discussed about the factors that influence the development of the industrial revolution, and the effect of rice production with the application of PTT and SRI technology. The purpose of this research is to describe and determine the influence of the development of the industrial revolution. This study uses a descriptive qualitative approach, which aims to determine the value of the variable, without creating, comparing, and looking for relationships. Sampling was carried out in this study by means of purposive sample. Purposive sampling is sampling by providing specific characteristics in accordance with the objectives of the study. The results showed that the biggest factor in influencing people's lives is the development of technology. The technology used to determine the level of application carried out in this study is the technology with the PTT method and the SRI method. The results of the two are very different, where the PTT method is more able to provide superior results. In the data it is noted that the SRI method in a certain period of time has decreased from season to season.
\end{abstract}

Keywords: Industrial Revolution, PTT, SRI, Purposive samples.

\section{Pendahuluan}

Perubahan yang cukup melejit sudah dialami oleh dunia dari tahun ke tahun. Negara yang tersebar di berbagai belahan dunia sedang

\footnotetext{
${ }^{*}$ Penulis Korespondensi.

E-mail: 2224200105@untirta.ac.id

Telp: +62-81315524344
}

berusaha supaya dapat beradaptasi dengan segala perubahan yang seiring terjadi setiap waktu. Perubahan-perubahan yang sering terjadi setiap waktu merupakan salah satu tanda bahwa dunia memasuki the era of industrial of industrial revolution 4.0 .

Sebelum kehidupan dunia memasuki industrial revolution era 4.0, dunia sudah dihadapkan dengan industrial revolution era 1.0 
sampai 3.0. (Ghufron, 2018) mengungkapkan bahwa industrial revolution era 1.0 ditandai oleh hadirnya proses mekanik dengan menggunakan tenaga mesin. Selain itu, era ini juga ditandai oleh adanya energi yang dihasilkan melalui uap dan air. Mulai dari revolusi tersebut, kehidupan di dunia mulai berubah. Aktivitas sehari-hari yang semula dilakukan oleh manusia dan hewan, mulai digantikan fungsinya oleh mesin. Mesin yang ketika itu dihasilkan adalah mesin uap. Mesin uap yang dihasilkan pada revolusi industri 1.0 merupakan sebuah achievement yang sangat menguntungkan karena dapat meningkatkan income hingga enam kali lipat setelah dua abad diterapkan (Ghufron, 2018). Peningkatan pendapatan yang sangat signifikan membuat perekonomian masyarakat menjadi lebih baik.

Setelah industrial revolution era 1.0 usai, industrial revolution era 2.0 mulai diterapkan dalam kehidupan dunia. (Ghufron, 2018) mengungkapkan bahwa industrial revolution era 2.0 dicirikan dengan adanya perkembangan dari motor penggerak dan energi listrik. Selain itu, revolusi industri ini juga ditandai oleh banyaknya manufaktur yang diproduksi secara massal. Tentunya, manufaktur tersebut sudah bukan diproduksi melalui tenaga manusia, melainkan melalui mesin.

Beberapa barang yang mulai diproduksi pada revolusi ini adalah pesawat terbang, telepon, dan kendaraan roda empat, yakni mobil.

Kemudian, industrial revolution era 3.0 mulai diterapkan dalam kehidupan dunia setelah industrial revolution era 2.0 usai. (Ghufron, 2018) mengungkapkan bahwa industrial revolution era 3.0 bercirikan dengan perkembangan teknologi yang semakin pesat, tepatnya teknologi informasi dan elektronik. Kedua teknologi tersebut mulai memasuki dunia industri sehingga pada revolusi ini juga sistem otomatisasi sudah mulai dikenal. melalui sistem otomatisasi yang mulai berkembang, kehidupan sehari-hari manusia menjadi lebih mudah. Hal tersebut disebabkan oleh adanya teknologi yang dapat melalukan kegiatan manusia dari jarak jauh. Teknologi tersebut adalah teknologi digital yang dapat dikendalikan oleh omputer dan robot melalui pengawasan manusia yang mampu dikontrol dari jarak jauh.

Setelah usainya industrial revolution era 3.0, industrial revolution era 4.0 mulai diterapkan dalam kehidupan dunia. Banyak sekali tanda yang dapat dijadikan sebagai ciri bahwa dunia memasuki era tersebut. Menurut Ghufron
2018, ciri-ciri industrial revolution era 4.0 meliputi adanya perkembangan dari internet atau for things. Perkembangan tersebut diwujudkan melalui penemuan teknologi baru dalam bidang sains, robotik, dan teknologi. Teknologi yang dimaksud dalam konteks ini adalah teknologi nano, tiga dimensi, serta kecerdasan buatan.

Industrial revolution era 4.0 merupakan revolusi keempat yang sedang dihadapi oleh kehidupan di dunia. Selain disebut dengan revolution industry 4.0, revolusi ini juga dapat disebut dengan era disrupsi serta digital revolution (Ghufron, 2018). Dikatakan sebagai era disrupsi karena dampaknya dapat membuat kehidupan dunia berubah secara drastis melalui inovasi-inovasi baru, khususnya dalam bidang sains dan teknologi. Di samping itu, dikatakan sebagai digital revolution karena kegiatan yang biasa dilakukan oleh manusia sehari-hari mulai dapat diterapkan teknologi digital. Berikut ini disajikan gambar perkembangan industry revolution yang pernah terjadi di dunia.

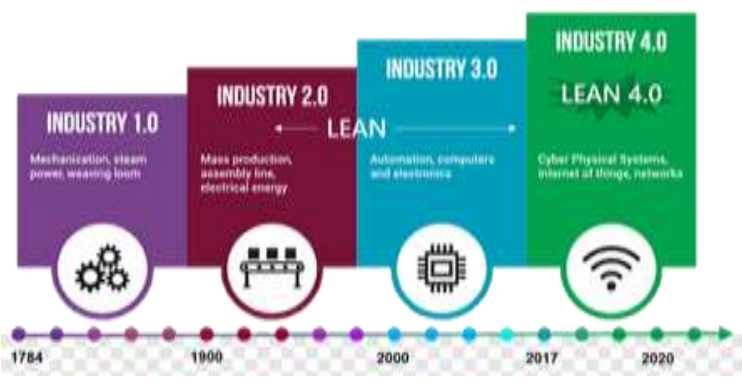

\section{Gambar 1. Perkembangan Revolusi Industri (Sumber: https://w7.pngwing.com)}

Seluruh revolusi yang pernah terjadi, tepatnya industrial revolution era 4.0 dapat membawa manfaat untuk kehidupan di dunia karena adanya kemudahan dari pengaruh penemuan-penemuan yang terus diperbarui. Penerapan artificial intelligence atau lebih dikenal dengan kecerdasan buatan dapat berdampak pada tenaga manusia yang menjadi semakin terkikis akibat fungsinya yang sudah digantikan oleh robot. Robot-robot yang mengalihfungsikan kegiatan manusia diciptakan melalui inovasi teknologi yang terus berkembang. Dalam hal ini, dapat disimpulkan bahwa industrial revolution era 4.0 dapat mengubah kegiatan manusia menjadi lebih efektif dan efisien karena manusia dapat memperluas ruang geraknya. Dengan kata lain, manusia menjadi lebih mudah melakukan mobilitas atau melakukan banyak kegiatan dalam satu waktu 
karena seluruh kegiatannya dapat dikontrol dari jarak jauh melalui pengaplikasian teknologi terbaru.

Akan tetapi, di samping membawa manfaat, revolusi tersebut juga sekaligus membawa tantangan dan ancaman untuk kehiduoan di dunia. (Kusnandar, 2019) mengatakan bahwa revolusi industry 4.0 membuat kehidupan manusia berada di ambang ketidakpastian. Sebelum masa depan datang, manusia perlu memikirkan segala aspek untuk hidup kedepannya. Hal tersebut dilakukan supaya manusia lebih mudah beradaptasi dengan perubahan yang terjadi secara singkat, tetapi terus menerus.

Selain itu, revolusi industrial revolution era 4.0 juga dapat mematikan usaha-usaha masyarakat yang masih bersifat tradisional. Usaha-usaha yang bersifat tradisional dapat mengalami pailit akibat tidak menyesuaikan teknologi terbaru. Akan tetapi, apabila menyesuaikan teknologi terbaru, dapat berimbas pada ketersediaan lapangan pekerjaan yang semakin sempit (Satya, 2018). Ketersediaan lapangan pekerjaan yang semakin sempit disebabkan oleh penciptaan robot-robot yang dapat mengalihfungsikan kegiatan manusia sehari-hari.

Tak hanya itu, perusahaan-perusahaan besar juga dapat berimbas akibat revolusi industri 4.0 (Kusnandar, 2019). Mengutip dari Satya 2018, Derasanya arus teknologi pada revolusi industri 4.0 membuat persaingan antara pebisnis semakin ketat. Mereka dapat menutupi fakta yang terjadi sehingga pesaing pun tidak terlihat secara nyata.

Oleh karena itu, untuk menghadapi seluruh tantangan dan ancaman pada revolusi industri 4.0, manusia dituntut supaya meng-upgrade dirinya setiap hari. Dengan begitu, mereka dapat menyesuaikan dirinya dengan perubahan yang terjadi melalui kemampuan yang memumpuni. Selain itu, mereka juga dapat membantu kemajuan suatu negara dengan cara memanfaatkan aspek yang unggul dari negara tersebut. sebagai contoh, masyarakat Indonesia dapat memanfaatkan dampak positif dari revolusi industri 4.0 dengan cara meningkatkan bidang pertanian, mengingata negara Indonesia dikenal sebagai negara agraris.

Bidang pertanian dapat ditingkatkan melalui pemanfaatan teknologi yang mengarah pada teknologi pertanian melalui inovasi-inovasi. Oleh karena itu, supaya dapat beradaptasi dengan perubahan dan ancaman akibat revolusi industri 4.0, petani dituntut untuk menguasai teknologi pertanian terkini yang inovatif sehingga dapat bersaing dengan petani lainnya. Untuk menguasai teknologi pertanian, petani diharuskan memiliki kemampuan dan keahlian pada bidang terkait sehingga ketahanan pangan rumah pangan para petani dapat meningkat.

Damba $d k k .$, (2020) mengemukakan bahwa efektivitas teknologi pertanian dipengaruhi oleh pemahaman dan kemauan petani dalam memanfaatkan dan menyerap inovasi pertanian sehingga distribusi hasil pangan, dalam hal ini pangan yang dimaksud adalah padi. Selain itu, faktor lain yang memengaruhi petani dalam memanfaatkan dan menyerap inovasi pertanian adalah adanya keterbatasan sumber informasi yang kurang menyebar di kalangan petani (Andriaty dan Setyorini, 2012). Oleh sebab itu, teknologi yang berbasis informasi perlu ditingkatkan, khusunya di kalangan petani.

Salah satu perkembangan teknologi pertanian yang dapat ditingkatkan oleh para petani adalah mobile technology. Mobile technology merupakan salah satu penemuan dari bidang pertanian yang tentunya mengandalkan teknologi terkini. Teknologi tersebut sangat bermanfaat dalam hal akses informasi karema petani dapat mengetahui komoditas pertanian dengan cara mengakses layanan informasi (Puspitasari, 2019). Dengan demikian, para petani sudah dapat mengefesienkan waktu untuk mencari tahu terkait harga bibit, luas tanaman, prediksi panen, atau segala hal yang berkaitan dengan komoditas pertanian. Tak hanya itu, petani juga dapat mengira-ngira harga di pasar karea perbedaan antara kondisi lapangan dengan data yang diperoleh tidak jauh berbeda.

Selain mobile technology, ada teknologi lain yang dapat diterapkan oleh petani, yaitu information technology (IT). Teknologi tersebut sangat berfungsi untuk petani dalam hal mengawasi komoditas pertanian yang ditanan karena dapat dikontrol dengan jarak jauh. Dengan demikian, petani tidak perlu bersusah payah pulang-pergi ke sawah untuk mengontrol sehingga kehidupan petani dapat lebih sejahtera dan pembangunan pertanian di suatu wilayah juga dapat berjalan dengan lancar.

\section{Tujuan dan Manfaat}

Berasarkan pendahuluan yang telah dipaparkan, jurnal ini disusun untuk mendeskripsikan pengaruh perkembangan 
teknologi pertanian di era revolusi industri 4.0 terhadap hasil produksi padi. Sementara itu, manfaat jurnal ini disusun supaya dapat bermanfaat untuk mengubah kehidupan petani tradisional menjadi modern dengan cara menerapkan teknologi atau inovasi pertanian terbaru sehingga dapat meningkatkan ketahanan pangan mereka.

\section{Metode Penelitian}

\section{Metode Penelitian}

Metode penelitian yang kami gunakan dalam penyusunan jurnal ini adalah metode pendekatan kualitatif deskriptif. Penelitian deskriptif merupakan penelitian yang bertujuan untuk mengetahui nilai variabel, baik satu variabel maupun lebih tanpa menciptakan, membandingkan serta mencari hubungan antara variabel yang satu dengan yang lainnya (Sugiyono, 2018). Pendekatan atau penelitian kualitatif merupakan metode penelitian yang berasaskan pada filsafat postpositivisme. Penelitian ini dipergunakan untuk meneliti kondisi objek yang alamiah, yang dimana peneliti menjadi instrumen kunci (Sugiyono, 2017). Dari kedua penelitian tersebut dapat disimpulkan bahwa metode deskriptif kualitatif merupakan metode yang dipakai untuk mendeskripsikan serta menggambarkan fenomena yang ada, baik itu bersifat alamiah ataupun rekayasa manusia, lebih memperhatikan karakteristik, kualitas, saling keterikatan antar kegiatannya (Sukmadinata, 2017).

\section{Sumber Data}

Dalam penyusunan jurnal ini, sumber data yang di gunakan adalah sumber data sekunder. Data sekunder merupakan data yang didapat melalui perantara yang saling berhubungan dengan penelitian yang sedang diteliti ini. Dengan kata lain, sumber tidak langsung memberikan informasi atau data kepada peneliti. Biasanya, sumber akan melalui perantara seperti orang lain atau dokumen, contohnya seperti buku, artikel, jurnal, dokumentasi berupa rekaman suara hingga foto yang akan dijadikan bukti bahwa penelitian ini benar-benar dilakukan (Sugiyono, 2016). Sumber data yang kami pakai berasal dari sumber bahan kepustakaan atau sumber bahan cetak, yaitu dengan menggunakan berbagai macam jurnal yang menjelaskan dan berhubungan dengan ketahanan pangan serta pengaruh teknologi pertanian terhadap hasil pangan.

\section{Teknik Pengumpulan Data}

Teknik pengumpulan data dan informasi yang dipakai dalam penyusunan jurnal ini adalah teknik pengumpulan data studi pustaka. Studi pustaka merupakan teknik pengumpulan data dengan menelaah setiap buku, literatur, jurnal, catatan, hingga laporan yang memiliki hubungan dengan permasalahan yang ada dan ingin dipecahkan permasalahanya. Teknik pengumpulan ini dipakai untuk mendapatkan dasar dan informasi, serta memperoleh pendapat yang tertulis yang dilakukan dengan membaca dan memahami literatur yang terkait dengan penelitian (Nazir, 2013).

\section{Teknik Analisis Data}

Teknik analisis data yang digunakan dalam penyusunan jurnal ini adalah teknik analisis data induktif. Proses pembahasan dalam analisis induktif ini meliputi macam-macam pola, tema, dan kategori yang berasas dari data. Analisis data dilakukan melalui tahapan pembahasan terhadap data yang telah dikumpulkan agar memiliki makna, baik berbentuk pola, tema, dan kategori. Tahapan-tahapannya yaitu menyusun data, lalu memasukan data tersebut kedalam komponenkomponen secara teratur, mensintesiskan data tersebut, setelah itu mencari pola-pola yang penting, lalu memutuskan apa saja yang harus di kemukakan. Analisis data induktif yaitu menarik kesimpulan yang berasal dari fakta-fakta yang telah terkumpul, yang kemudiakan akan di tarik kesimpulannya.

\section{Hasil dan Pembahasan}

\section{Perkembangan Revolusi Industri}

Perkembangan terknologi yang ditandai dengan adanya revolusi industri 1.0 hingga revolusi industri 4.0 merupakan salah satu faktor yang dapat memengaruhi kehidupan masyarakat. Perkembangan teknologi pada saat ini lebih dikenal dengan istilah era revolusi industri 4.0. 
Era ini ditandai dengan berkembangnya teknologi dan informasi sebagai alat bantu yang berfungsi untuk memudahkanpekerjaan manusia (Mumtaha dan Halwa, 2019). Dalam era ini, teknologi dapat menggantikan tenaga manusia dengan mesin. Adapun rangkaian perkembanan di era Revolusi Industri tertera pada gambar 2.

Gambar 2. Perkembangan Revolusi Industri

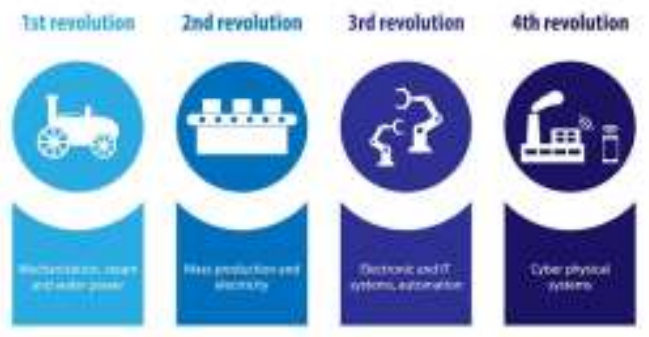

(Sumber: https://images.app.goo.gl)

\section{Faktor-Faktor yang Memengaruhi Perkembangan Revolusi Industri}

Faktor-faktor yang memengaruhi perkembangan revolusi Industri dimulai dari revolusi industri 1.0. Era industry 1.0 ditandai dengan adanya keamanan politik dan stabilitas ekonomi Inggris. Inggris merupakan sumber bahan baku industri dan wilayah penjualan produk manufakur yang telah jadi. Kemudian, dilanjut dengan revolusi industri 2.0. Era industri 2.0 ditandai dengan adanya hal yang menjadi faktor perkembangan revolusi, yaitu perkembangan teknologi dan sosial budaya. Hal tersebut menyebabkan banyaknya inovasi yang muncul di era ini, seperti berkembangnya industri berbasis ilmu pengetahuan dan teknologi. Selanjutnya adalah revolusi industri 3.0. Era revolusi 3.0 ditandai dengan ditemukannya teknologi informasi dan elektronik yang memasuki dunia industri,misalnya, sistem otomatisasi dan robot. Dalam hal ini, peralatan industri tidak dikendalikan lagi oleh manusia karena sudah tergantikan oleh robot dan sistem otomatisasi. Selanjutnya adalah era saat ini, yaitu era revolusi industri 4.0. Era revolusi industri 4.0 ditandai dengan adanya konektivitas manusia, data, dan mesin dalam bentuk virtual (Kusnandar, 2019).
Hasil Produksi Padi dengan Tingkat Penerapan Teknologi (PTT) dan System of Rice Intensification (SRI)

Hasil produksi pangan sangat berpengaruh pada metode yang digunakan oleh para petani. Jurnal ini berfokus pada dua metode yang ada dalam teknologi pertanian, yaitu tingkat penerapan teknologi (PTT) dan system of rice intensification (SRI) yang banyak dikembangkan di Indonesia. Metode SRI merupakan metode dengan menggunakan pupuk organik tanpa penambahan pupuk kimia. hal tersebut dapat menyebabkan hasil yang kurang maksimal dibandingkan dengan metode PTT. Metode PTT merupakan metode dengan menggunakan pupuk kimia dan organik sebagai media pemupukan. Dari kedua teknologi tersebut diketahui memiliki hasil yang sangat berbeda. Hal ini membuktikan bahwa metode SRI tidak mampu memberikan hasil seperti pada metode PTT, bahkan pada produktivitas padi dengan menggunakan metode SRI dalam batas kurun waktu tertentu tercatat turun dari musim ke musim (Abdulrachman, 2012).

Tabel 1. Komponen Teknologi dan Komponen Input Produksi Pada 2 Model Pendekatan Usaha Tani Padi di Sukamandi, 2008-2009.

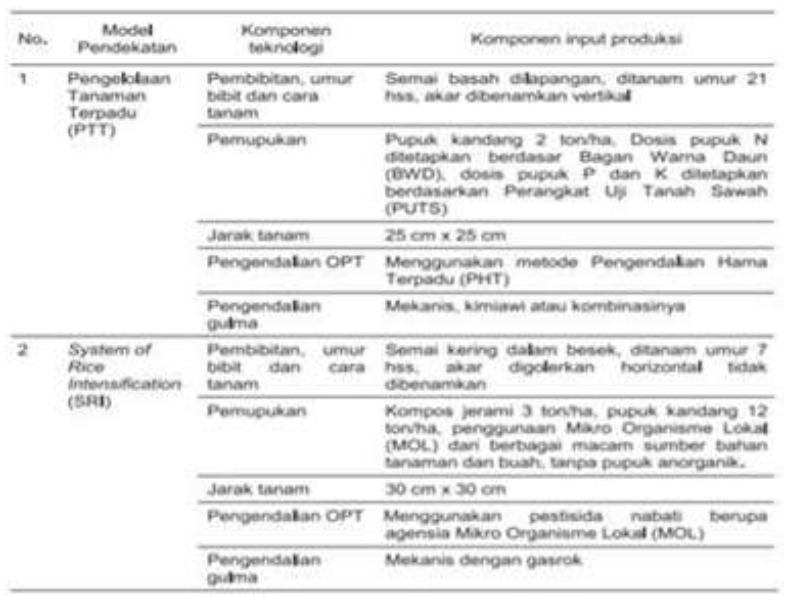

Hasil analisis kualitas fisik beras Tentang MK-1 dan MK-2, 2009 Rendemen beras pecah kulit dan rendemen Metode penggilingan padi PTT lebih baik Dibandingkan dengan metode SRI. Selain Metode PTT memiliki persentase Beras atau persentase beras yang lebih tinggi Pecahnya lebih sedikit dibandingkan metode SRI Hal tersebut dapat dilihat pada Tabel 3. Dalam metode PTT Ada juga persentase menir dan biji- 
bijian Biji jeruk nipis lebih rendah dari metode SRI. Kekurangan nutrisi fosfor dan kalium Sangat mencurigai bahwa penggunaan metode SRI akan mengarah pada Kualitas fisik beras kurang bagus.

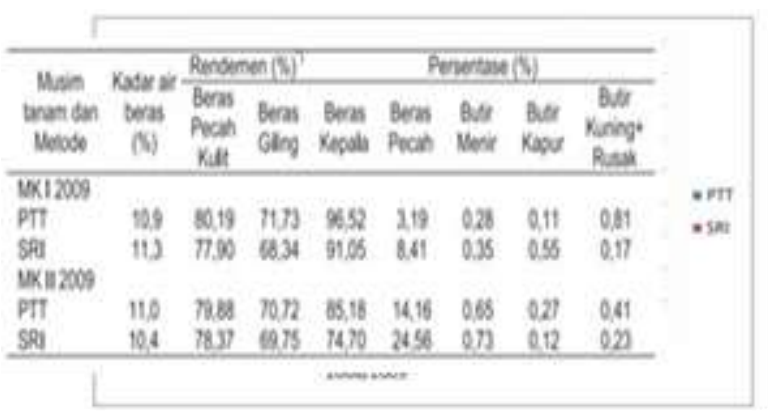

\section{Kesimpulan}

Perkembangan teknologi di era revolusi industri 4.0 dapat memengaruhi kehidupan dan kesejahteraan masyarakat saat ini. Hal ini ditandai dengan semakin berkembangnya teknologi di bidang pertanian. Salah satu teknologi pertanian yang berpengaruh terhadap hasil produksi pangan berupa padi di Indonesia saat ini adalah mobile dan information technology. Sementara itu, dua metode yang efektif yang dapat digunakan dalam bidang pertanian, yaitu metode PTT dan SRI.

Berdasarkan hasil penelitian pada dua model pendekatan usaha tani selama 4 musim tanam dapat diambil kesimpulan bahwa;

1. Hasil gabah dengan menggunakan metode PTT (penyerbukan menggunakan 2 pupuk yaitu: pupuk organik dan anorganik) lebih banyak dibandingkan dengan hasil gabah menggunakan metode SRI.

2. Mutu beras yang dihasilkan melalui metode PTT lebih berkualitas dibandingkan dengan mutu beras menggunakan metode SRI.

\section{Ucapan Terima Kasih}

Ucapan terima kasih penulis sampaikan kepada Bu Dr. Rida Oktorida Khastini, M.Si. selaku dosen mata kuliah Ketahanan pangan sekaligus pembimbing dalam penulisan jurnal ini. Beliau selalu memberikan arahan, nasihat, serta motivasi kepada penulis. Selain itu, penulis juga sampaikan kepada teman-teman, khususnya teman kelompok yang telah berkontribusi besar dalam pembuatan jurnal ini.

\section{Daftar Pustaka}

Ali, A. (2017). Pengaruh Teknologi Pertanian Terhadap Produktivitas Hasil Panen Padi di Kecamatan Maritengngae Kabupaten Sidenreng Rappang. Jurnal Ilmiah, 14(3), 514525.

Andriaty, E., \& Setyorini, E. (2012). Ketersediaan Sumber Informasi Teknologi Pertanian di Beberapa Kabupaten di Jawa. Jurnal Perpustakaan Pertanian, 21(1), 3035. DOI: https://doi.org/10.21082/jp p.v21n1.2012.p.

Apriani, M., Rachmina, D., \& Rifin, A. (2018). Pengaruh Tingkat Penerapan Teknologi Pengelolaan Tanaman

Terpadu (Ptt) Terhadap Efisiensi Teknis Usaha Tani Padi. Jurnal Agribisnis Indonesia, 6(2), 121-132. DOI: https://doi.org/10.29244 /jai.2018.6.2.121-132

Fatchiya, A., Amanah, S., \& Kusumastuti, Y. I. (2016). Penerapan Inovasi Teknologi Pertanian dan Hubungannya dengan Ketahanan Pangan Rumah Tangga Petani. Jurnal Penyuluhan, 12(2), 190-197.

Ghufron, M. A. (2018). Revolusi Industri 4.0: Tantangan, Peluang dan Solusi Bagi Dunia Pendidikan. Jurnal Seminar Nasional dan Diskusi Panel Multidisiplin Hasil Penelitian dan Pengabdian Kepada Masyarakat, 332-337.

Habtewold, T. M. (2021). Impact of ClimateSmart Agricultural Technology on Multidimensional Poverty in Rural Ethiopia. Journal of Integrative Agriculture, 20(4), 1021-1041. DOI: https://doi.org/10.1016/S20953119(21)636 37-7.

Junaedi, A., Chozin, M. A., \& Kim, K. (2006). Perkembangan Terkini Kajian Alelopati. Jurnal Hayati, $\quad$ 13(2), 79-84. DOI:https://doi.org/10.1016/S1978- 3019(1 6)30386-2.

Mahbubi, A. (2013). Model Dinamis Supply Chain Beras Berkelanjutan. Jurnal Manajemen dan Agribisnis, 10(2), 81-89. 
Martina. (2017). Penerapan Teknologi Pertanian Pada Usaha Tani Padi Sawah di Kecamatan Muara Batu Kabupaten Aceh Utara. Jurnal Agrifo, 2(1).

Mayadewi, N. N. A. (2010). Inovasi Teknologi Pada Komoditas Padi Bagi Keberlanjutan Pembangunan Pertanian. Jurnal Dwijen AGRO, 2(2), 1-15.

Mislaini \& Fahmy, K. (2017). Penerapan Teknologi Pertanian melalui Penggunaan Alsintan pada Lahan Sawah Kepada Masyarakat Tani di Nagari Minangkabau Kec. Sungayang Kab. Tanah Datar. Jurnal Ilmiah Pengabdian Kepada Masyarakat, 24(2), 52-72. DOI: https://doi.org/10.25077/logista.1.1.2938.2017.

Mulyono, J., \& Munibah, K. (2016). Strategi Pembangunan Pertanian di Kabupaten Bantul dengan Pendekatan A'WOT. Jurnal Pengkajian dan Pengembangan Teknologi Pertanian, 19(3), 199-211.

Nasihien, R. D., Wulandari, D. A. R., Zacoeb, A., Harimurti, \& Setiawan, I. (2017). Teknologi Portable Inflated Greenhouse sebagai Fasilitas Pendukung Peningkatan Ketahanan Pangan dan Pertanian Perkotaan (Urban Farming). Jurnal Darussalam: Jurnal Pendidikan, Komunikasi dan Pemikiran Hukum Islam, 9(1), 161-183. DOI: http://doi.org /10.30739/darussalam.v9i1.123.

Nazir, Moh. 2013. Metode Penelitian. Bogor: Penerbit Ghalia Indonesia.

Nugroho, S., \& Budianto, M. J. (2014). Journal of Economics and Policy, 7(2), 100-202.

DOI: http://dx.doi.org/10.15294/jejak.v7i1.3596.

Nuryanti, S., \& Swastika, D. K. S. (2011). Peran Kelompok Tani dalam Penerapan Teknologi Pertanian. Jurnal Forum Penelitian Agro Ekonomi, 29(2), 115-128. DOI: https://doi.org/10.21082/faev29n2 .2011.115-128.

Puspitasari, R. D. (2019). Pertanian Berkelanjutan Berbasis Revolusi Industri 4.0. Jurnal Layanan Masyarakat, 3(1), 26-28. DOI: https:/ /doi.org/10.20473/jlm.v3i1.2019.26-28.
Putranto, A. W., Sugiarto, Y., Kusumarini, N., Wiranti, T., \& Normalasari, L. (2018). Pengaruh Pemberian Pupuk Urea dan Jarak Elektroda terhadap Tegangan Plant Microbial Fuel Cell Tanaman Padi (Oryza sativa). Jurnal Teknologi Pertanian, 19(1), 43-50.

Santoso, T. J., Sudarsono, Aswidinnoor, H., \& Somantri, I. H. (2005). Daya Regenerasi Padi Indica cv. Bengawan Solo dalam Dua Tipe Media Regenerasi dengan Penembakan Mikroproyektil. Hayati Journal of Biosciences, 12(4), 157-161. DOI: $\quad$ https://doi.org/10.1016/S1978 3019(16)30344-8.

Saputra, M. W., \& Ratnawilis. (2019). Dampak Teknologi Pertanian Modern terhadap Aktivitas Pertanian Padi Masyarakat di Jorong Piruku Utara Kecamatan Sitiung Kabupaten Dhamasraya. Jurnal Buana,3(2), 205-216. DOI: https://doi.org/10 .24036/student.v3i2.337.

Satya, V. E. (2018). Strategi Indonesia Menghadapi Industri 4.0. Jurnal Pusat Penelitian Badan Keahlian DPR RI, 10(9), 19-24.

Sugiyono. (2015). Metode Penelitian Kuantitatif, Kualitatif dan R\&D. Bandung: Penerbit Alfabeta.

Sugiyono. (2016). Metode Penelitian Kuantitatif, Kualitatif dan R\&D. Bandung: Penerbit Alfabeta.

Sugiyono. (2018). Metode Penelitian Kuantitatif. Bandung: Penerbit Alfabeta.

Sukmadinata, N, S. (2017). Metode Penelitian Pendidikan. Bandung. Remaja Rosdakarya.

Sumarno. (2006). Peranan teknologi dalam mendukung ketahanan pangan nasional. Jurnal Pusat Penelitian dan Pengembangan Tanaman Pangan Bogor, 38-47.

Yanti, V. A., Amanah, S., Muldjono, P., \& Asngari, P. (2018). Faktor-Faktor yang Mempengaruhi Keberlanjutan Usaha Pelaku UMKM di Bandung dan Bogor. Jurnal Pengkajian dan Pengembangan Teknologi Pertanian, 20(2), 137-148. 